\title{
SELLING FAVORS IN THE LAB: EXPERIMENTS ON CAMPAIGN FINANCE REFORM
}

\author{
DANIEL HOUSER \\ THOMAS STRATMANN
}

CESIFO WORKING PAPER NO. 1727

CATEgory 2: Public CHOICE

MAY 2006

Presented AT CESifo AREA CONFERENCE ON

ApPlied Microeconomics, MARCH 2006
An electronic version of the paper may be downloaded
- from the SSRN website: $\quad$ www.SSRN.com
- from the RePEc website: Www.RePEc.org
- from the CESifo website: www.CESifo-group.de




\title{
SELLING FAVORS IN THE LAB: EXPERIMENTS ON CAMPAIGN FINANCE REFORM
}

\begin{abstract}
Substantial academic interest and public policy debate centers on campaign finance reform. Campaign resources can provide benefits to constituencies if candidates use them to fund the distribution of useful information. On the other hand, voters can potentially be harmed if candidates trade policy favors to special interests in exchange for contributions. Unfortunately, because informative field data on this topic are very difficult to obtain, the effects of different campaign finance strategies on election outcomes and economic welfare remain largely uninformed by empirical analyses. This paper reports data from novel laboratory experiments designed to shed light on the campaign finance debate. Our experiment is based on a model where power-hungry candidates are motivated to trade favors for campaign contributions. Our data is consistent with the model's predictions. We find that voters' revise their beliefs in response to candidate advertising in a way that is consistent with theory. Moreover, in relation to privately financed electoral competitions, in publicly financed campaigns (i) high-quality candidates are elected more frequently, and (ii) margins of victory are larger. Both of these outcomes are predicted by theory. We conduct policy experiments on various campaign finance strategies, including the widely suggested caps on private fundraising. Our results suggest that caps can improve voter welfare but do not increase the likelihood that high-quality candidates will be elected.
\end{abstract}

JEL Code: D72, C9.

\author{
Daniel Houser \\ Department of Economics \\ Center for Study of Public Choice \\ George Mason University \\ MSN 1D3 - Carow Hall \\ 4400 University Dr. \\ USA - Fairfax, VA 22030 \\ dhouser@gmu.edu
}

\author{
Thomas Stratmann \\ Department of Economics \\ Center for Study of Public Choice \\ George Mason University \\ MSN 1D3 - Carow Hall \\ 4400 University Dr. \\ USA - Fairfax, VA 22030 \\ tstratma@gmu.edu
}

November, 2005

The authors are grateful to the International Foundation for Research in Experimental Economics for funding that supported this research. Discussions with Stephen Coate have been particularly valuable. Will Christie provided help with software, running experiments and the data. Participants at the following conferences provided useful comments on this paper: Public Choice (2004), Southern Economic Association (2004), Midwest Political Science Association (2005), and Economic Science Association (2005). We also thank attendees of the CIRANO Policy Conference in Ottawa (2005) for helpful feedback. Bridget Butkevich, Jennis Taylor, Dorina Tila and Erte Xiao provided valuable assistance with experiments. 


\section{Introduction}

Substantial academic interest, along with an increasingly passionate policy debate, centers on campaign finance reform. Campaign resources can provide benefits to constituencies if candidates use them to fund the dissemination of useful information. On the other hand, voters can potentially be harmed if candidates trade policy favors to special interests in exchange for contributions. While there has been significant theoretical progress on this topic, informative field data are very difficult to obtain. Consequently, the effects of different campaign finance strategies on election outcomes and economic welfare remain largely uninformed by empirical analyses. This paper reports data from novel laboratory experiments designed to shed light on the campaign finance debate.

A number of theoretical models assume that campaign contributions are used in electoral races to provide information to voters, but that candidates obtain contributions by promising favors (see for example Plotters, Sloof, and van Winden 1997, Coate 2004a, 2004b and Prat 2001, 2002). ${ }^{1}$ Within this framework scholars analyze welfare consequences stemming from the introduction of campaign contribution limits (i.e. comparing the loss in information to voters to the gain from fewer policy favors to contributors). All of these formal theories, along with their attendant results, rely on assumptions regarding voters' beliefs, and the way those beliefs change in light of candidates' advertising. Unfortunately, little is known about the empirical validity of these theories or assumptions, a fact that is echoed in the ongoing public debate over this issue. U.S. Senator Mitch McConnell (R-Kentucky), for example, claims that most contribution limits

\footnotetext{
${ }^{1}$ Other theoretical work in this area of research that either views campaign advertising as providing information, or that views campaign expenditures as providing signals includes Ashworth (2003), Austen-Smith (1987), Bailey (2002, 2004), Baron (1994), Groseclose (2001), Schultz (2003), Abrajano and Morton (2004), and Wittman (2004a, 2004b). Related theoretical work in this area includes Hinich and Munger (1989), Simon (2002) and Morton and Myerson (2003). Morton and Cameron (1992) review much of the older theoretical literature on campaign
} 
amount to incumbent protection acts. Former Commissioner Bradley A. Smith (Federal Election Commission) similarly argues that campaign finance laws make it relatively harder for challengers to raise money vis-à-vis incumbents (Smith 1995). On the other hand, those who favor contribution limits claim that they level the playing field, and reduce both actual and apparent corruption.

Indirect evidence regarding the welfare consequences of campaign policies can be drawn from previous research with field data. For example, the literature linking campaign spending to vote shares hints at welfare effects, but does not provide a direct test of the effect of campaign finance restrictions. Work in this area includes, e.g., Jacobson (1980, 1985, 1989, 1997), Abramowitz (1988), Green and Krasno (1988), Levitt (1994) and Gerber (1998). Also, Stratmann (2004) reports data that suggest the effectiveness of campaign spending depends on whether states have campaign contributions caps, but he is also unable to offer direct evidence on any associated welfare consequences.

Direct field comparisons of welfare effects of different campaign finance policies are extremely difficult to accomplish. It is for this reason that, despite its evident academic interest and public policy importance, no comparative empirical analysis of the welfare implications of different campaign finance policies has yet appeared. The reason for the difficulty is that the net benefit of different policies depends crucially on the way voters' decisions are affected by costly advertising under different campaign finance programs. Direct inferences about this type of voter behavior would seem to require (i) individual-level observations on number of ads seen and voting decisions, and (ii) observations from at least two states (or counties or other political units) that are very similar outside of their campaign finance policies. In our experience, data of

expenditures. 
this sort are unavailable.

The importance of the topic, along with the severe limitations in using field data to explore it, motivates us to pursue an experimental approach. In a laboratory campaign contribution rules are treatment variables, candidate's qualities are known and voters' decisions are fully observable. Consequently, direct inferences regarding comparative welfare effects are possible.

To discipline our experiment's design we looked to previous theoretical research on contribution limits. In the end, much of our design reflects an environment developed by Coate (2004a). A reason for this choice is that Coate's model makes stark and testable predictions that certain campaign policies have Pareto improving welfare effects. However, it is important to emphasize that our data inform more than just Coate’s model. Indeed, our environment shares key features with many well-known formal models, particularly the models cited above, in which voters are assumed to revise their beliefs in response to candidate advertising. Our experiment informs such formal theory, in that our data provide evidence on the nature and consequences of voter belief updating, as well as how such updating differs among various campaign finance institutions. These issues have not been analyzed experimentally previously, and we provide a novel experimental design for this purpose. ${ }^{2}$

In our experiment power-hungry candidates run for office, and voters vote for their preferred candidate. Candidates can obtain contributions in one treatment though a quid-pro-quo with interest groups, and in another treatment though public financing. Our findings lend support to formal theory, in the sense that voters in our laboratory campaigns update their beliefs in a

\footnotetext{
${ }^{2}$ Of course, many experiments test theories in both individual and strategic decision making environments (see, e.g., Houser, et. al. (2004) for the former, and Kurzban and Houser (2005) and Houser and Kurzban (2002) for the latter.)
} 
direction predicted by the rationality assumptions typically incorporated into theoretical political economy models (such as those cited above). In particular, we find strong evidence that the effectiveness of campaign advertising, and consequently electoral outcomes and voter welfare, depend on voters' beliefs regarding the degree to which a campaign was financed with monies obtained though a quid-pro-quo. Our empirical confirmation of the substantive importance of campaign finance policy leads us to design experiments to investigate welfare effects of frequently suggested campaign policies including contribution caps and public matching funds. We report the results of these experiments in section IV below.

\section{A Political Competition Model}

We here detail a model that illuminates the trade-offs associated with certain forms of campaign finance policy. As noted above, this model is drawn from Coate (2004a). The model provides testable predictions with respect to the effect of contribution limits on the closeness of electoral races, and how voters react when faced with campaign advertising under different campaign finance regimes. Our experiment then provides data that tests these predictions.

The model assumes a first-past-the-post electoral rule, two candidates, and a

one-dimensional policy space. Voters (and contributors) seek to bring about the feasible outcome that maximizes their respective utilities. Voters are either leftist, rightist, or swing voters. Swing voters are symmetrically distributed around the median of the one-dimensional space, with leftist voters to the left, and rightist voters positioned to the right. Swing voters are either left-leaning or right-leaning.

There are two parties and each party selects a candidate. Candidates are citizens and have fixed ideologies. The leftist party selects a candidate from leftist voters and the rightist party 
selects a candidate from rightist voters. There are an equal number of rightist and leftist voters, and the platforms of candidates reflect their parties’ positions. In addition to their positions, candidates are characterized by their types. A candidate is either a "high quality" or "low quality" type, reflecting the idea that parties cannot always find a high quality person to serve as their candidate. In the model, parties choose the candidate's type with an exogenous probability. The type captures a candidate's innate characteristics, such as competence, the quality of his past performance and valence, including personal characteristics like integrity.

A leftist voter will always vote for a candidate from the leftist party, regardless of his type. Similarly, a rightist voter will always vote for a candidate from the rightist party. Swing voters differ in their ideal points because some swing voters are left-leaning while others are right-leaning. Swing voters’ preferences are homogeneous with respect to candidate quality and valence. They prefer a competent politician and a politician with integrity over a politician without such characteristics and tend to vote for the qualified candidate. However, they are "rationally ignorant" and thus have little knowledge of whether candidates are of high or low quality. Each swing voter has beliefs about the likelihood that candidates are qualified. In the absence of information on candidate quality, left (right) leaning swing voters will vote for the candidate from the leftist (rightist) candidate.

There are two interest groups. The leftist group contributes to the leftist candidate and the rightist group contributes to the rightist candidate, and interest groups observe the quality of their own party's candidate but not the quality of the opposing party's candidate. Candidates use the contributions for campaign advertising. Advertising is truthful, meaning that candidates advertise their own records and characteristics and cannot lie about their past records and 
characteristics. ${ }^{3}$ Advertising is beneficial for the high quality candidate because it may induce some swing voters to change their votes. The low quality candidate will not advertise since this will only reduce the chances of election.

Since party extremists will always vote for their candidate, the outcome of the election is determined by the behavior of swing voters. For example, in equilibrium a left-leaning swing voter faces four possibilities: i) he has not seen the advertisement from either party’s candidate, ii) he has seen the advertisement from both party's candidates, iii) he has seen the leftist party’s advertisement but not the rightist party's advertisement, and iv) he has seen the rightist party’s advertisement but not the leftist party’s advertisement. In the first three cases he will vote for the leftist party. In the last case he might vote for the rightist candidate. He knows that the rightist candidate is qualified, but he is uncertain about the leftist candidate. Whether he will vote for the rightist candidate depends on how likely he thinks it is that the rightist candidate is qualified and on his idiosyncratic preferences to vote for the leftist candidate. In equilibrium, some fraction of left-leaning swing votes in situation (iv) will switch to their vote to the rightist candidate.

Coate adds the critical assumption that candidates obtain contributions by promising policy favors to the contributors. ${ }^{4}$ Policy favors decrease the utility of voters. In this case left leaning swing voters in (iv) are less likely to switch their vote to the rightist candidate because they know that the right candidate promised at least some favors to the interest group in exchange for obtaining campaign funds. Thus, promising favors to contributors can be costly to candidates. Had fewer favors been sold, the campaign message would have been more

\footnotetext{
${ }^{3}$ One rationale for this assumption is that news media have incentives to reveal when an advertisement is not truthful, and this provides incentives for candidates to air credible advertisements.

${ }^{4}$ Supporting evidence for the assumption of a quid-pro-quo between legislators and interest groups has been provided in a number of studies, including Stratmann $(1998,2002)$. Additional theoretical work in this area includes Grossman and Helpman (1994, 1996, 2001).
} 
convincing and the probability that the voter would switch his vote to the advertising candidate would have been higher.

In Coate’s (2004a) model, the margin of victory between the high and low quality candidates diminishes (relative to the case where advertising is purely informative and no favor trading has taken place) because voters know about the quid pro quo and thus become cynical about candidates because even qualified candidates sell favors. This makes advertising less effective. With unrestricted contributions and unrestricted favor selling (candidates are infinitely power hungry), the informational value of advertisements becomes very small, and contribution limits could increase the high quality candidate’s vote share.

This model also provides testable implications regarding the effect of publicly versus privately financed political campaign. The model predicts that relative to privately financed campaigns, publicly financed campaigns increase the high quality candidate's chance of winning the election, and this is the source of the welfare improvements that Coate ties to publicly financed campaigns. Public advertising is the case of purely informative advertising. No promises have to be made to contributors when advertising is paid by taxpayers.

Finally, this model provides testable implications regarding the effect of campaign contribution limits on the closeness of elections. Dollar limits on contributions can reduce the number of policy favors candidates promise to interest groups. While campaign contribution limits result in less campaign spending ${ }^{5}$ and reduce voters' information about their voting options, limits may decrease the number of favors candidates promise to contributors. The probability that a voter will switch his vote to the advertising candidate will increase with limits

\footnotetext{
${ }^{5}$ Coate's (2004) model assumes that contribution limits translate into fewer overall contributions raised and thus into lower campaign expenditures.
} 
if the beneficial effects of limits, i.e. fewer policy favor promises, outweigh the negative effects of information loss (Coate 2004a).

\section{Experiment Design}

\section{Overview}

Our experiment is implemented entirely on computers using software we created specifically for campaign finance experiments. After subjects are seated in the laboratory, all advertising and voting are accomplished through the software. Instructions for our experiment are also computerized. A transcript of the instructions can be found in the appendix.

Our experimental design is guided by the model described in Section II. To summarize the above, key features of that model are:

- There are two political parties representing opposing ideologies.

- One candidate represents each party, and each candidate might be high or low quality.

- Candidates always prefer to be elected.

- "Swing" voters might vote for a candidate outside of their own party, if they believe that candidate is sufficiently qualified.

- Voters know each candidate’s party, but not whether he/she is qualified.

- Advertising provides truthful information about a candidate’s quality.

- Resources for advertising are obtained from interest groups for whom elected candidates are able to provide favors, so that larger contributions can be exchanged for increased promises of (conditional) favors.

A broad characterization our experiment is as follows. Each session includes multiple rounds. In each round, two subjects are chosen at random to be candidates, one for each party. 
Half of the remaining subjects, the voters, are randomly assigned to each party (experiments are always run with an even number of subjects.) Political parties are represented by "triangle” or “circle”, and quality by "striped” or "solid”. One candidate is randomly assigned to be "solid," and the other "striped.” Subjects' incentives are structured so that all voters are swing voters: all prefer striped shading to solid shading, but within a shading prefer a candidate of their own party.

Voters know the party of each candidate (triangle or circle) but not their shading (solid or striped.) During campaigns candidates purchase advertisements that provide truthful information to voters about his/her shading. Each purchased advertisement reaches exactly one randomly chosen subject. After the campaign voters cast a vote for exactly one candidate.

Rather than modeling interest groups directly, in our experiment candidates use tokens to purchase advertisements. The crux of our experiment is that tokens come in different colors, red and blue, with blue tokens costly to voters if the elected candidate used them to buy advertisements. Red tokens are never costly to voters. Loosely speaking, the idea is that candidates who use blue tokens have financed their advertising by selling favors, while candidates who use red have financed with "clean” public money.

Some experimental treatments include only red tokens, while in others only blue tokens are available. Both voters and candidates know the nature of each treatment and when they are in each treatment. For example, all subjects are told when they will participate in an "only blue" treatment, and all subjects understand that this means that any advertising is accomplished with only blue tokens. Comparing electoral outcomes across treatments provides a simple and direct way to assess the effect of various types of campaign finance policies. 
It is important to point out that although our subjects are provided substantial information about each treatment, they nevertheless have less knowledge than agents in the model sketched in Section II above.. In particular, in that model agents have correct beliefs (in equilibrium) about the amount of high quality candidate spending. In our experiment, subjects face uncertainty with respect to the amount of high quality candidate spending: they must draw inferences about this quantity based on the number of ads they receive. Consequently, subjects' behavior in our experiments should be sensitive to number of ads seen, while in Coate's model all that matters is whether agents receive at least one ad (and consequently identify a candidate as high quality). ${ }^{6}$

\section{Particular Specifications}

\section{Voters' Earnings}

Voters' payoffs are determined by (i) the party of the elected candidate; (ii) the shading of the elected candidate; and (iii) the number of blue tokens used by the winning candidate to purchase advertisements. Ignoring for the moment the cost of blue tokens, let $\mathrm{P}(\mathrm{x}, \mathrm{y})$ denote the baseline payoff to a voter if a candidate of party " $\mathrm{x}$ " and shading " $\mathrm{y}$ " is elected. Then the payoff structure is $\mathrm{P}($ own party, striped $)=7.5>\mathrm{P}($ other party, striped $)=7.0>\mathrm{P}($ own party, solid $)=5.0$ $>\mathrm{P}($ other party, solid $)=4.5$. Each of these payoffs is expressed in experimental points, which are converted at a known exchange rate (three to one) to US dollars at the end of the experiment. As pointed out above, the voter payoff structure ensures that all voters in our experiment are "swing” voters, in the sense that they always prefer a striped to solid candidate, although within

\footnotetext{
${ }^{6}$ In an extended footnote, Coate sketches a framework within which number of ads seen matters: voters draw inferences about how power hungry a candidate is based on the number of ads they have seen (Coate, 2004a, fn. 22, pp. 642-3). This is essentially what subjects in our experiment must do.
} 
shadings voters prefer a candidate from their own party.

Although voters are not explicitly told the color of the token used to buy a given advertisement, they are given complete information about each treatment. For example, voters know if only blue tokens are available for candidates to buy advertising. The use of blue tokens can reduce voters’ earnings, while red tokens never reduce voters’ earnings. In particular, 0.5 points are deducted from each voter's earnings for every blue token used by a winning candidate. Consequently, total earnings for each voter, if a candidate of party $\mathrm{x}$ and shading $\mathrm{y}$ is elected and used $\mathrm{N}$ blue tokens and $\mathrm{M}$ red tokens to advertise, is given by $\mathrm{P}(\mathrm{x}, \mathrm{y})-\mathrm{N}(\mathrm{blue}) / 2-0 * \mathrm{M}$ (red).

Note that voters will lose experimental points if they elect a candidate who used more than 15 blue tokens to purchase advertising. Losses carry over to subsequent rounds, but subjects are aware that earnings over the entire experiment are bounded below by zero.

\section{Candidates’ Earnings}

Candidates earn 15 experimental points if they win an election. Candidates are charged 0.1 points to buy an advertisement, regardless of the token's color. That is, both blue and red tokens are costly to candidates. However, candidates do not incur the 0.5 point cost per blue token they use if they are elected. The reason is that we want candidates to be strongly motivated to win the election, regardless of the amount of advertising that they do or the way it is financed. With regard to Coate's model, one can interpret this as ensuring that our candidates are "power hungry.” Moreover, candidates do not incur the blue token cost if the other candidate is elected. The reason is that we did not want candidates to enter cooperative agreements not to advertise, or to advertise little, in order to avoid this cost. Candidates' earnings E are therefore calculated by the formula: 


$$
\mathrm{E}=\mathrm{I}(\text { win the election)*15 }-0.1 * \text { (Number of advertisements purchased.) }
$$

Note that non-winning candidates who purchase advertisements will lose experimental points.

\section{Campaigning}

Each campaign lasts for one minute. During that minute candidates can use tokens to purchase advertisements. Exactly one subject receives each advertisement, and this subject is drawn randomly from the entire set of participants. Consequently, during any campaign some subjects might see more than one advertisement, while others see none. In addition, candidates can receive each other's ads, and candidates can receive their own ads. Candidates know how many ads they have sent, and know the color of the tokens used to purchase ads, but do not know anything about the voters who have received their ads. This eliminates the possibility of “targeted” advertising. Figures A1 and A2 display what candidates and voters see during the campaigning phase of each round in the experiment. 
Figure A1

Example of Screen Voters See During Campaign

Time Remaining: 0:56

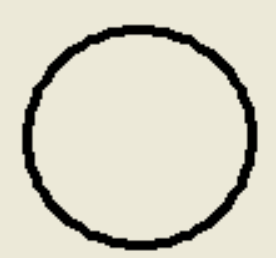

My party affiliation: Circle Party
My Earnings if the Following Candidate is Elected:

(Excluding Blue Token Penalty)
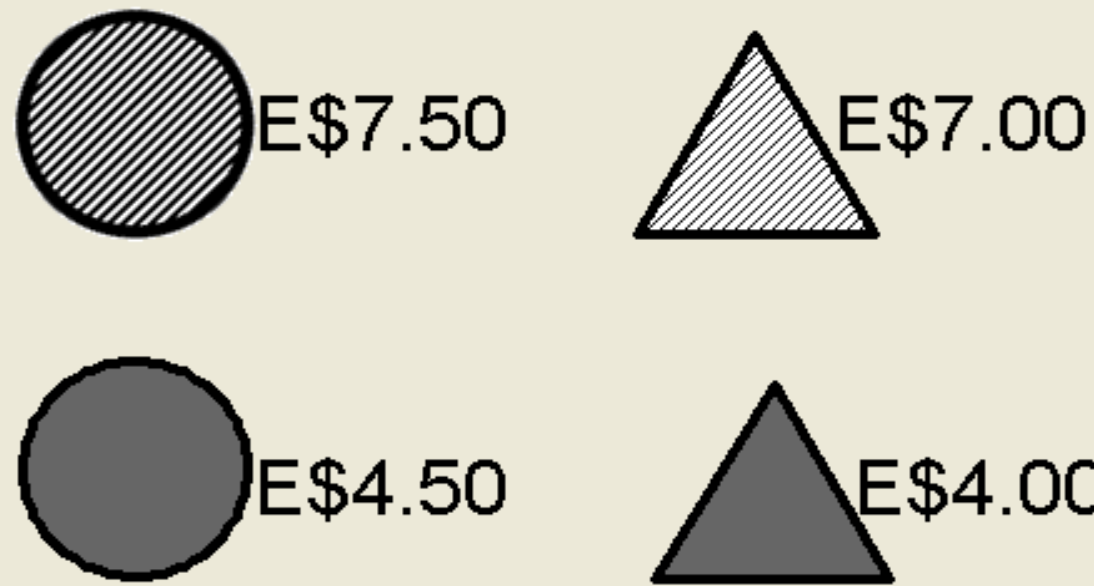

\section{Advertisement Monitor:}

(How many advertisements I have seen from each

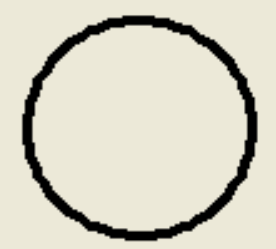

Circle candidate: 0

Advertisements

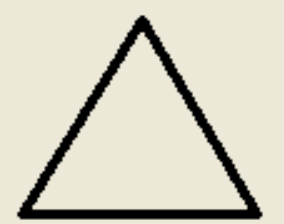

Triangle candidate: 0 Advertisements 
Figure A2

Example of Screen Candidates See During Campaign

G. Candidate

Campaigning

Time Remaining: $0: 56$

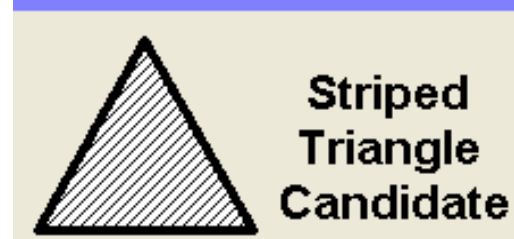

Buy Advertisement:

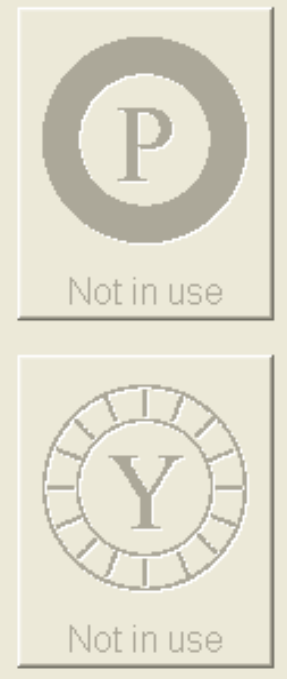

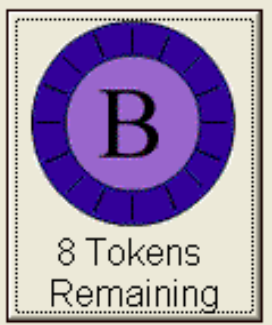

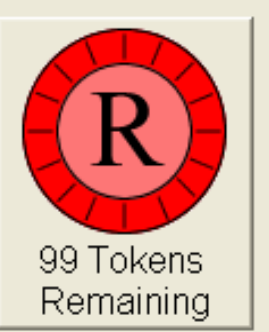

My Transactions \begin{tabular}{l|l|} 
Transaction \# & Token Color Used \\
\hline
\end{tabular}
Advertising History:

(Tokens spent by color)
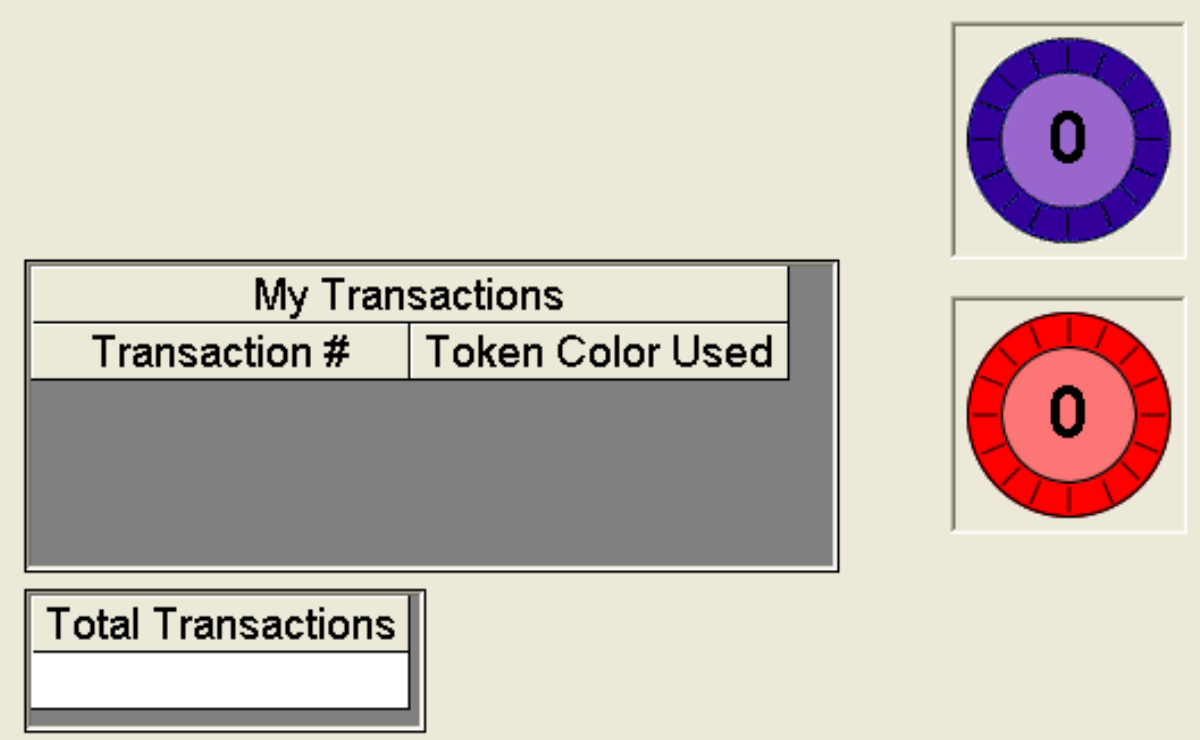


\section{Figure A3}

Example of Voting Screen

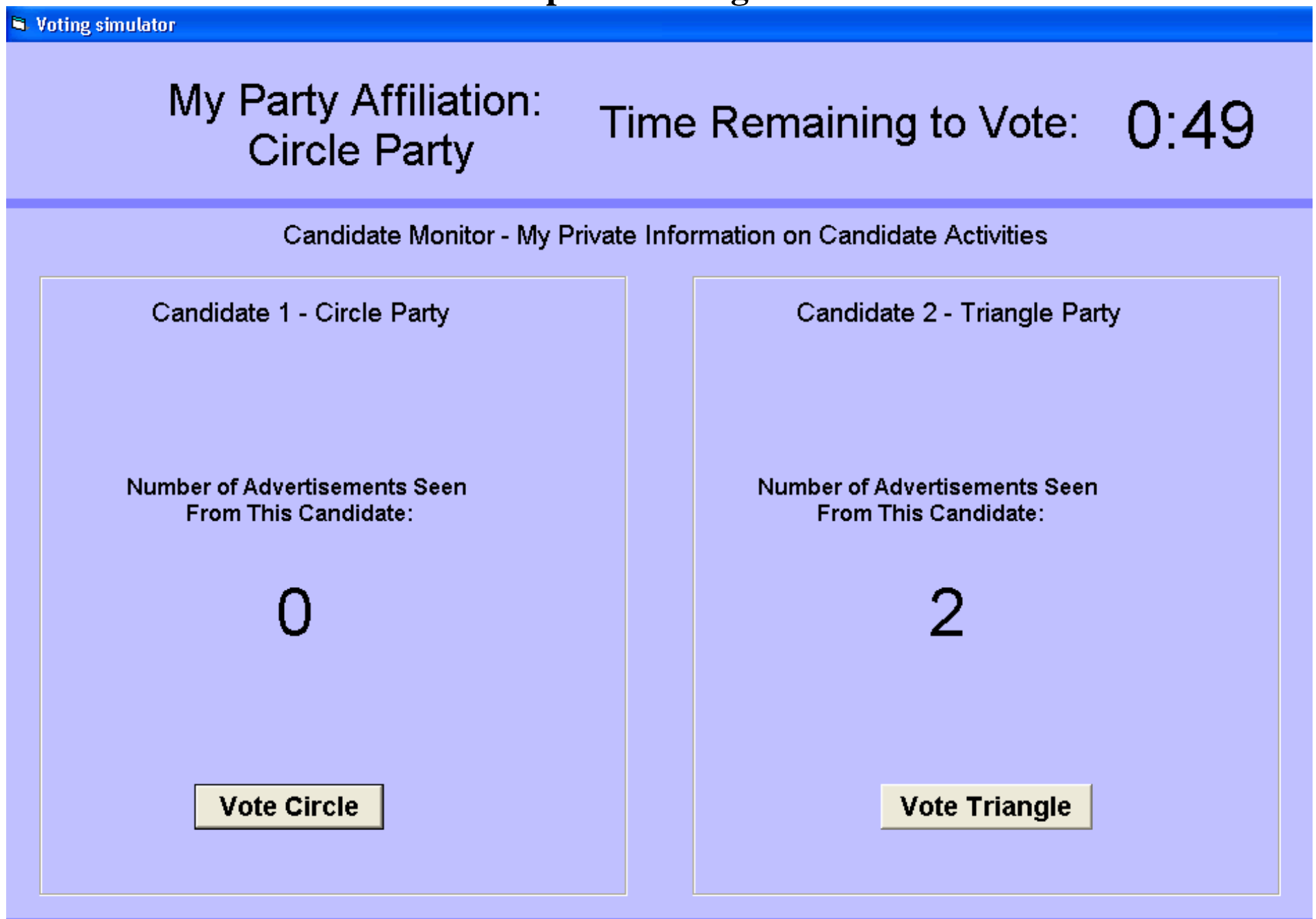




\section{Voting}

Voting immediately follows campaigning. Within 30 seconds of the end of the campaign voters must cast a vote for one of the candidates. Voting is mandatory. During the voting phase the screen reminds subjects of the number of ads from each candidate that they have seen. Figure A3 displays the screen subjects see during voting.

\section{Implementation}

Subjects are recruited using the automated recruiting system in place at the Interdisciplinary Center for Economic Science, George Mason University. After arriving subjects provide written consent to participate in the experiment, and are instructed that no communication is allowed once the experiment has begun. Subjects are escorted into the laboratory and seated at a desk that is separated from other desks by high partitions. Once seated, subjects complete electronic instructions that include an interactive quiz. Subjects who answer sufficiently many questions incorrectly are approached by the experimenter and appropriately assisted.

After all subjects have successfully completed the instructions, they are acquainted with the software interface by running through a non-interactive demonstration version of each possible scenario: candidate campaigning, voter during campaign, and voting. Subjects are told at this time that mouse-clicking is not necessary during the experiment: all necessary decisions can be executed via "mouse-over." That is, to execute a decision a subject need only move the cursor over an appropriate area on the screen that corresponds to that action. Eliminating clicking is necessary because we needed to eliminate all information, outside of receiving an advertisement, regarding the amount of candidate activity during campaigns. In addition, using 
mouse-overs eliminates an annoying source of laboratory noise.

After completing the instructions and non-interactive demonstration, subjects practice two interactive campaigns. No money is earned during the practice rounds. The practice rounds give subjects a chance to see how the experiment actually works, and to ask any final questions that might arise as a result of this exposure.

After the instructions, demonstration and practice subjects begin money rounds. At the beginning of each round subjects are informed as to the conditions of that round. For example, they will be told that the next campaign will include only blue tokens. At the round's beginning subjects are also informed what role they will play in that round: voter or candidate, party affiliation and, if a candidate, whether they are solid or stripes. Although candidates are chosen randomly each round, this randomization is constrained so that no subject can be a candidate twice before all subjects are candidates at least once.

At the end of each round a results screen describes for each subject the outcome of the election, the amount he/she earned, and the cumulative amount that he/she has earned over the course of the experiment. Subjects are not told how many campaigns will be included in the experiment, nor are they informed as to the distribution of treatments.

\section{Results}

We report data from eight experimental sessions, each of which included either 24 or 26 subjects. Each of these sessions included between eight and fifteen campaigns. This provided a total of 2,509 observations on the voting decisions of 194 subjects. Subjects were paid privately at the end of each experimental session, which lasted about two hours. Subjects earned about \$35 on average. The inferences that we report are based on panel data estimation procedures that 
control for both subject and session effects.

The hypotheses that motivated our investigation revolve around the way in which voters respond to candidates' advertising in different treatments. Within any campaign, any given voter's decision can depend on (i) her party affiliation; (ii) the number of ads that she received from each candidate and (iii) the information provided by the ads she saw. As a practical matter, the number of low-quality candidate advertisements was very low, and we will exclude from our analysis those cases where a subject saw an ad from a low quality candidate. Consequently, a voter's decision can be modeled as a function of both her party, as well as the number of ads that she received from the high quality candidate. To be precise, consider the case that a voter with party affiliation $\mathrm{L}$ receives two ads from the high quality candidate who is party $\mathrm{R}$. Then the probability that this L voter casts a vote for the high quality R candidate can be written:

$$
\operatorname{Pr}\left(V_{L}(2) \succ C_{H}(R)\right)
$$

Here, $V_{L}(2)$ indicates that voter $\mathrm{V}$ of party $\mathrm{L}$ has received 2 ads from the high quality candidate, and $\succ$ indicates "will vote for", and $C_{H}(R)$ denotes that the high quality candidate is affiliated with the R party.

Now, suppose that a high quality candidate affiliated with the R party advertised $n$ times during a campaign. Extending the notation above, the probability that a randomly selected voter from the population will vote for the high quality candidate of the R party can be written as follows. 


$$
\begin{aligned}
\operatorname{Pr}(V \succ & \left.C_{H}(R) \mid n\right)= \\
& \operatorname{Pr}\left(V_{R}(0) \succ C_{H}(R)\right) \operatorname{Pr}\left(V_{R}(0) \mid n\right) \operatorname{Pr}\left(V_{R}\right)+ \\
& \operatorname{Pr}\left(V_{R}(1) \succ C_{H}(R)\right) \operatorname{Pr}\left(V_{R}(1) \mid n\right) \operatorname{Pr}\left(V_{R}\right)+ \\
& \operatorname{Pr}\left(V_{R}(2) \succ C_{H}(R)\right) \operatorname{Pr}\left(V_{R}(2) \mid n\right) \operatorname{Pr}\left(V_{R}\right)+ \\
& \operatorname{Pr}\left(V_{R}(>2) \succ C_{H}(R)\right) \operatorname{Pr}\left(V_{R}(>2) \mid n\right) \operatorname{Pr}\left(V_{R}\right)+ \\
& \operatorname{Pr}\left(V_{L}(0) \succ C_{H}(R)\right) \operatorname{Pr}\left(V_{L}(0) \mid n\right) \operatorname{Pr}\left(V_{L}\right)+ \\
& \operatorname{Pr}\left(V_{L}(1) \succ C_{H}(R)\right) \operatorname{Pr}\left(V_{L}(1) \mid n\right) \operatorname{Pr}\left(V_{L}\right)+ \\
& \operatorname{Pr}\left(V_{L}(2) \succ C_{H}(R)\right) \operatorname{Pr}\left(V_{L}(2) \mid n\right) \operatorname{Pr}\left(V_{L}\right)+ \\
& \operatorname{Pr}\left(V_{L}(>2) \succ C_{H}(R)\right) \operatorname{Pr}\left(V_{L}(>2) \mid n\right) \operatorname{Pr}\left(V_{L}\right)
\end{aligned}
$$

The first line on the right hand side of (1) is the probability that the randomly selected voter is affiliated with the R party, and has received zero advertisements, and will vote for the candidate of the R party. The second line is the same, except that the randomly selected voter has received one advertisement, and similarly for the remaining six lines.

Although the notation has been suppressed, each type of campaign is associated with its own equation (1). It is easy to show that if we can determine each of the 24 probabilities that enter each treatment's equation (1), then we will be able to inform all of the hypotheses of interest. For example, note that the first probability in each line of (1) reflects the way voters update their beliefs in the face of advertisements. The model sketched in Section II requires these probabilities to be different in different types of campaigns, and in particular ways. In particular, that model implies that in publicly financed campaigns the probability that a voter will vote for the high quality candidate, conditional on seeing multiple ads from that candidate, would be near one. This would not be the case in the blue campaigns, where sophisticated voters should be less willing to vote for a high quality candidate from whom they have seen frequent advertisements.

The design of our experiment enables us to quickly determine the second two probabilities on each line. These quantities will be the same for each treatment. For example, if 
there are 26 subjects and 12 voters in each party then $\operatorname{Pr}\left(V_{R}\right)$ is 12/26. Similarly, because each ad reaches exactly one person, and that one person is drawn randomly from the population of subjects, we can use numerical procedures to quickly calculate how the number of ads sent affects the expected fraction of subjects who will receive $0,1,2$ or more ads. These probabilities are provided in Table A1.

The first probability on each line of (1) is not determined by our design, but rather by subjects' decisions in each treatment. The challenge is to estimate these quantities from the available data. It is clear these quantities are identified. For example, to estimate the probability that a triangle voter who has seen zero ads would vote for a circle candidate, one could simply find the frequency in the data that this occurred. However, this simple frequency calculation would not take account of the panel structure of the data, which leads to well-known difficulties in interpreting the precision of the estimates.

An alternative approach, and the one that we pursue, estimates these quantities within a panel data framework. In particular, we estimate each probability that enters (1) separately for each treatment using a mixed effects probit where the dependent variable is the decision to vote for the high quality candidate, and the independent variables are the number of ads received. We include random individual effects and fixed effects for sessions. We exclude from our analysis all cases where a subject received any ads from a low quality candidate. The reason is that we are interested in the link between high quality advertising and voting outcomes, and this link is obscured in those cases where the low quality candidate advertises. Ads from the low quality candidate were seen by 118 (not necessarily unique) voters, leaving us with 2,391 observed voting decisions upon which to base our analysis.

Our estimates of the effect of advertising on the probability of switch-voting for high and 
low quality candidates are detailed in Tables 1 and 2, respectively. All of the estimates include random subject effects. In all cases but one we included fixed session effects. ${ }^{7}$ The included regressors varied depending on empirical identification issues. In the case of Blue campaigns, we have enough variation in the data to obtain separate inference regarding the effects on voters of receiving one, two or more than two ads. As we will discuss below, in Blue Cap campaigns the amount of advertising was restricted and consequently there were few cases where subjects saw more than one advertisement. Accordingly, we draw inference about the effect of seeing "at least one” advertisement. We do the same for Red campaigns, but for a different reason. In this case the behavior was nearly identical regardless of the number of ads seen (they just voted for the high quality candidate as soon as that information was revealed), and the appropriate model was one that included only a single regressor to summarize the effect of advertising.

A casual inspection of the Tables quickly reveals that while switch voting for the high quality candidate is affected by advertising in all cases, it is only in Blue campaigns where switch voting for the low quality candidate is substantially effected by advertising. To understand this, note that the probability of voting for your own party in the absence of seeing advertisements is about 95\% in all cases. Hence, advertising can only have a visible effect (in our relatively small sample) in one direction: it must reduce the chance that a voter will cast her ballot for her own party’s high quality candidate. So, Table 2 immediately reveals that seeing own-party ads in Blue campaigns reduces the chance of voting for that candidate, while it has a statistically weaker effect in all other cases, and essentially no effect in Red and Matching campaigns.

The coefficients in Tables 1 and 2 can be difficult to interpret. Consequently, we used the

\footnotetext{
${ }^{7}$ The exception occurs in Red campaigns when we examine the effect of ads on switch-voting for the low quality
} 
point estimates reported in those tables to create Figure 1, which provides a convenient graphical depiction of the relevant implications of our estimates. Consider for now only the Blue and Red campaigns. Panel (a) describes the probability that a high quality candidate will receive a vote from someone of their own party, conditional on the number of ads the voter has seen from that high quality candidate. As noted above, if no advertisement is received, so that the voter has no information regarding which candidate is high quality, there is a $95 \%$ chance that the voter will cast her vote for the candidate of her own party, and this is true in both the Red and Blue treatments. The baseline 5\% switch rate could reflect "hunches" or might be due to errors.

The effect of received ads on vote probabilities varies, however, between the Red and Blue campaigns. In Red campaigns, a voter who receives one or more ads from an own-party high quality candidate will cast their vote for that candidate with near probability one. But in Blue campaigns, the probability that a voter casts their ballot for an own-party high quality candidate declines with the number of ads that she has received. In fact, if she receives three or more ads, there is less than a $40 \%$ chance that they will cast their ballot for that candidate. This difference between the Blue and Red campaigns is statistically significant, and lies in direction predicted by Section II's model.

Voters' reactions to advertisements in Red campaigns are optimal, in the sense that they vote for high quality candidates after receiving their ads. Voters' reactions in Blue campaigns are in the direction predicted by theory, but there is a sense in which they do not move quickly enough away from their own candidate. In particular, a simple calculation reveals that there is only about a $4 \%$ chance that a single voter (out of 24 ) could have received two ads from a single candidate who advertised less than six times. Consequently, in our environment receiving two

candidate. This almost never occurs: the variation in the data is not substantial enough to identify session effects. 
ads from a candidate is a very strong signal that they have advertised more than five times, which would leave any non-advertising candidate an expected earnings maximizing choice. The fact that voters do not strongly defect from their own candidate might suggest that they are pessimistic about the advertising by a candidate about whom they have no information, or that they are optimistic about the behavior of their own party's candidate, or that they are confused about the probability implications of receiving more than one ad from a single candidate.

Panel (b) in Figure 1 describes how the probability that a voter will support an otherparty high quality candidate varies the number of ads received from that candidate. In Red campaigns, voters who receive at least one add from an other-party high quality candidate will actually vote for that candidate with probability 0.95 , which is consistent with earnings maximizing behavior. In blue campaigns the probability is $47 \%$ conditional on receiving one or more ads. Again then, the probability of switch voting is different between Red and Blue campaigns, and in a way that is consistent with Section II's model of political competition.

We next detail the welfare and electoral outcome implications of this voter behavior.

\section{IV.1. Campaign Finance Policy Effects on Electoral Outcomes and Welfare}

Result 1: In Red treatments the high quality candidate lost the election only once out of 18 campaigns, and in that case the candidate did not advertise. The high quality candidate in blue campaigns lost seven of 32 campaigns, and in six of those cases there was positive advertising.

Note also that the high quality candidate tied in one red campaign with positive advertising. The outcome was also a tie in six blue campaigns, all of which included positive advertising. The next finding extends Result 1. 
Result 2: Greater advertising leads to greater margins of victory in Red campaigns. Advertising is effective in Blue campaigns, but the margin of victory is non-monotonic in the number of ads.

This is made clear in Figure 2. This figure plots the relationship between margin of victory and voting as implied by the estimates of equation (1), along with the actual data from the experiment. Although the estimates of equation (1) imply that advertising is always expected to result in a positive margin of victory (at least for advertising in the range we observed), this margin is expected to be much smaller in Blue than in Red campaigns. Indeed, the expected margin of victory is non-monotonic in advertising in Blue campaigns. It achieves a maximum of about four votes with 25 ads, but diminishes to two votes when 50 ads are sent. This is reflected by the actual data from the experiment (which of course underlie the estimates the parameters of equation (1).) Among all 32 Blue campaigns, the actual margin of victory never exceeded 10 votes, and achieved this level only once. The next highest margin of victory was six, achieved only three times. Moreover, higher advertising clearly does not help much in Blue campaigns: in one case a high-quality candidate advertised 49 times but achieved a margin of victory of only four votes.

In contrast, the expected margin of victory in Red campaigns is strictly increasing in advertising. Among the actual Red campaigns the greatest margin of victory was 18, and this occurred in a case where the number of ads sent was 48. Unlike Blue campaigns, excessive advertising is apparently not viewed negatively by voters in Red campaigns.

Result 3: In both Blue and Red campaigns, the number of switch-party votes received by a candidate is positively correlated with the number of ads the candidate sends.

This result is apparent from Figure 3. Panel (a) reflects behavior in Blue campaigns, and 
panel (b) Red campaigns. In both panels the vertical axis is the number of switch votes for the high quality candidate, and the horizontal axis is the number of ads. In Red campaigns, where advertising is not costly to voters, we saw above that essentially all voters who receive an ad from the high quality candidate are expected to vote for that candidate. In Blue campaigns the link is less strong but still positive. Among the actual campaigns, Figure 3 shows that the maximum number of switch votes for the high quality candidate is six in Blue campaigns, and nine in Red campaigns. The simple correlations between number of ads and switch votes are 0.63 in Blue campaigns, and 0.81 in Red campaigns. 


\section{Figure 1}

\section{(Panel A)}

Probability of Voting for Own Party Striped Candidate by Number of Striped Ads Received and Treatment

(a)

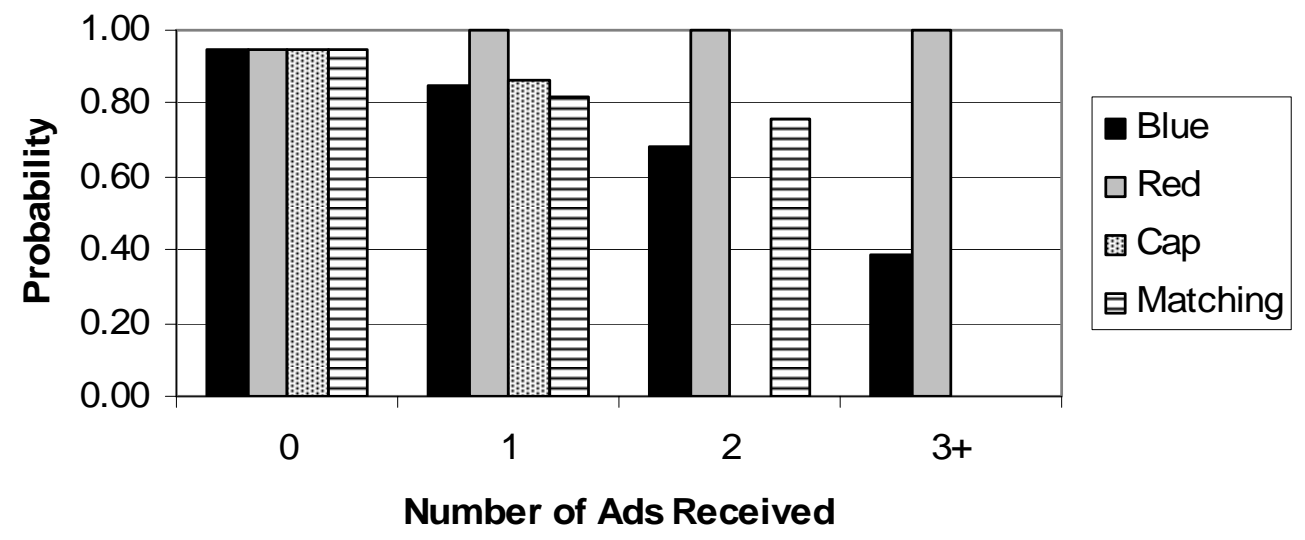

(Panel B)

Probability of Voting for Other Party Striped Candidate by Number of Striped Ads Received and Treatment

(b)

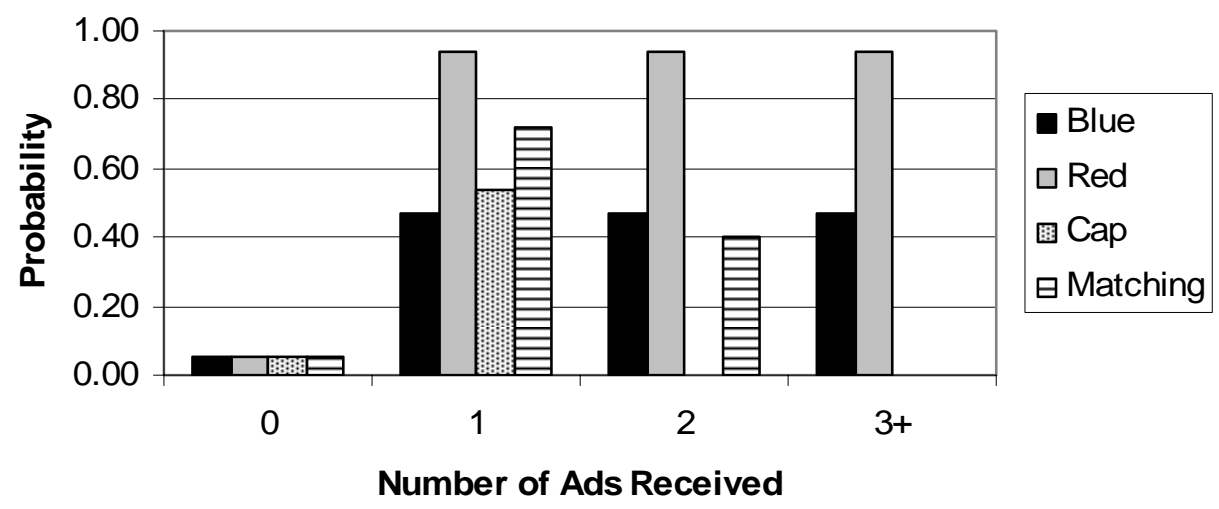


Figure 2

\section{Expected and Actual Margin of Victory}

by Number of Ads

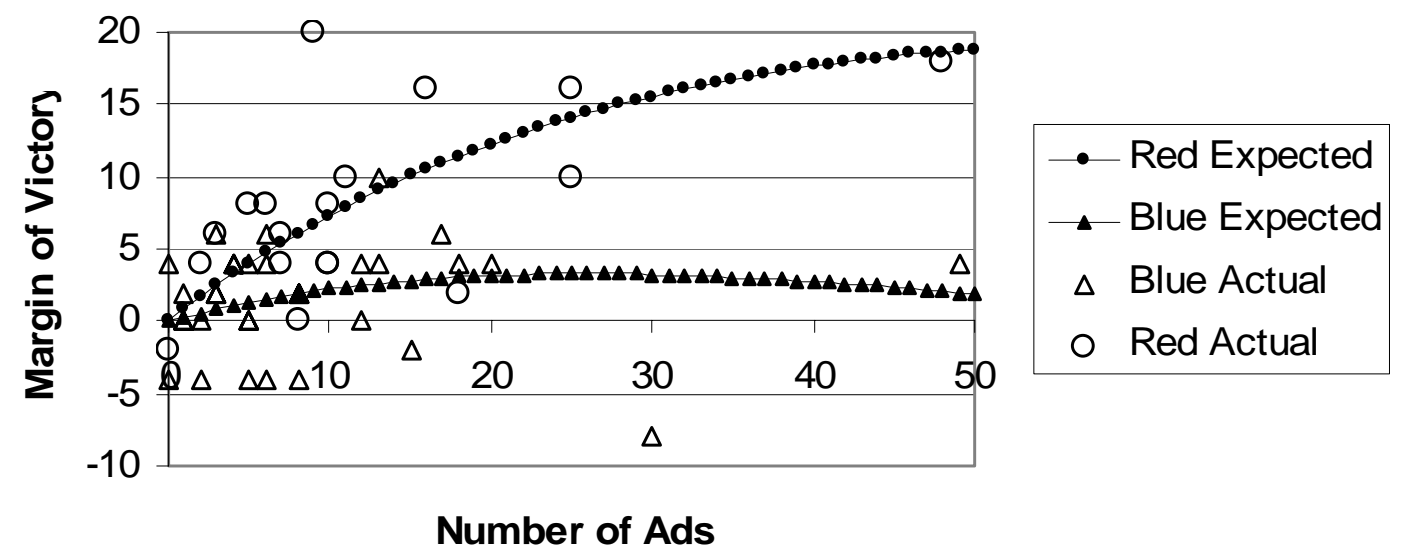


Figure 3

Expected and Actual Aggregate Switch Votes

Blue Campaigns

(a)

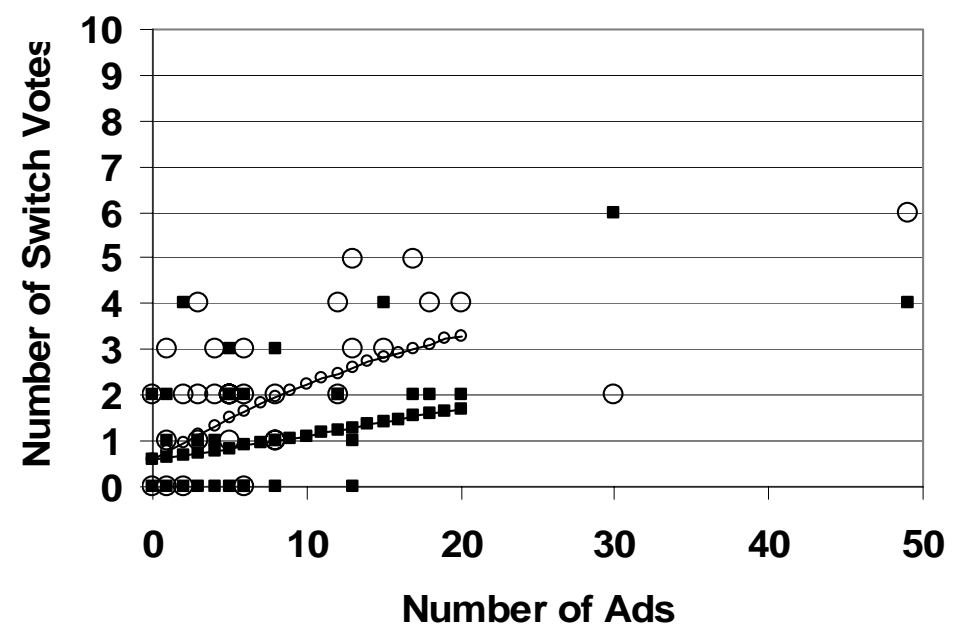

$\rightarrow$ Expected Switch Striped

○ Actual Switch Striped

--Expected Switch Solid

- Actual Switch Solid

Expected and Actual Aggregate Switch Votes

Red Campaigns

(b)

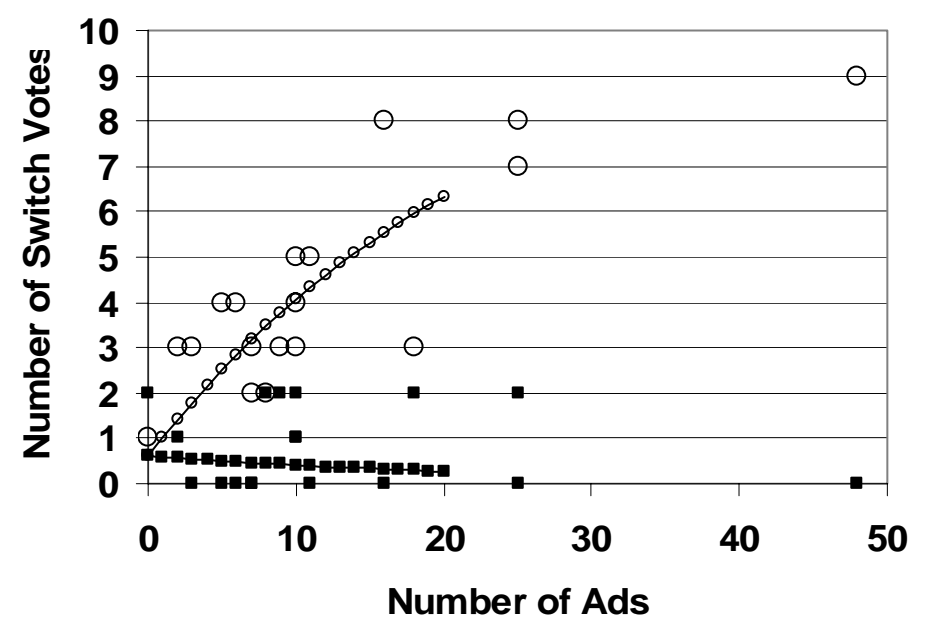
$\rightarrow$ Expected Switch Striped

○ Actual Switch Striped

- Expected Switch Solid

- Actual Switch Solid 
Result 4: In Blue campaigns, number of advertisements is positively related to number of ownparty votes against the high quality candidate. There is no evidence of this in Red campaigns.

This result says that, in Blue campaigns, a high quality candidate will lose some of his own party voters if he advertises too often, but that this does not happen in Red campaigns. This finding is easily seen in Figure 3. This provides the explanation for the simultaneous findings that margins of victory are not tightly connected to number of ads in Blue campaigns, while switch voting for the high quality candidate is. We see from Figure 3, and also the estimates of equation (1) for Blue campaigns as reported in Figure 1, that greater advertising in Blue campaigns brings with it the risk that some own-party voters can receive multiple ads, and consequently become concerned that too much advertising is being purchased with "dirty" money. In actual Red campaigns this never occurred more than twice. On the other hand, in one Blue campaign that included 30 ads, six of that high quality candidate's own-party voters cast a ballot against him. This effect attenuates the margin of victory that high quality candidates in Blue campaigns can achieve.

Result 5: The ex-post socially optimal outcome was achieved 89\% of the time in Red campaigns, but only $69 \%$ of the time in the Blue campaigns.

Figure 4 describes this result. Here, the social benefit is calculated after the campaign phase is completed, and is defined as the post-campaign value of electing the qualified candidate minus the post-campaign value of electing the unqualified candidate. In both cases, "value” is determined by aggregating subjects' earnings in the event of a candidate's election. In Blue campaigns where the high quality candidate has advertised six or more times this difference will 
be negative. This difference will never be negative in Red campaigns. Note that, for the purpose of this calculation, campaigns that end in a tie are not considered to have achieved the socially optimal outcome. This result is consistent with Section II's model: there is an expected social benefit to moving from special interest to public financed campaigns.

Figure 4

\section{Margin of Victory and Net Aggregate Benefit of Electing Striped Candidate \\ Blue and Red Campaigns}

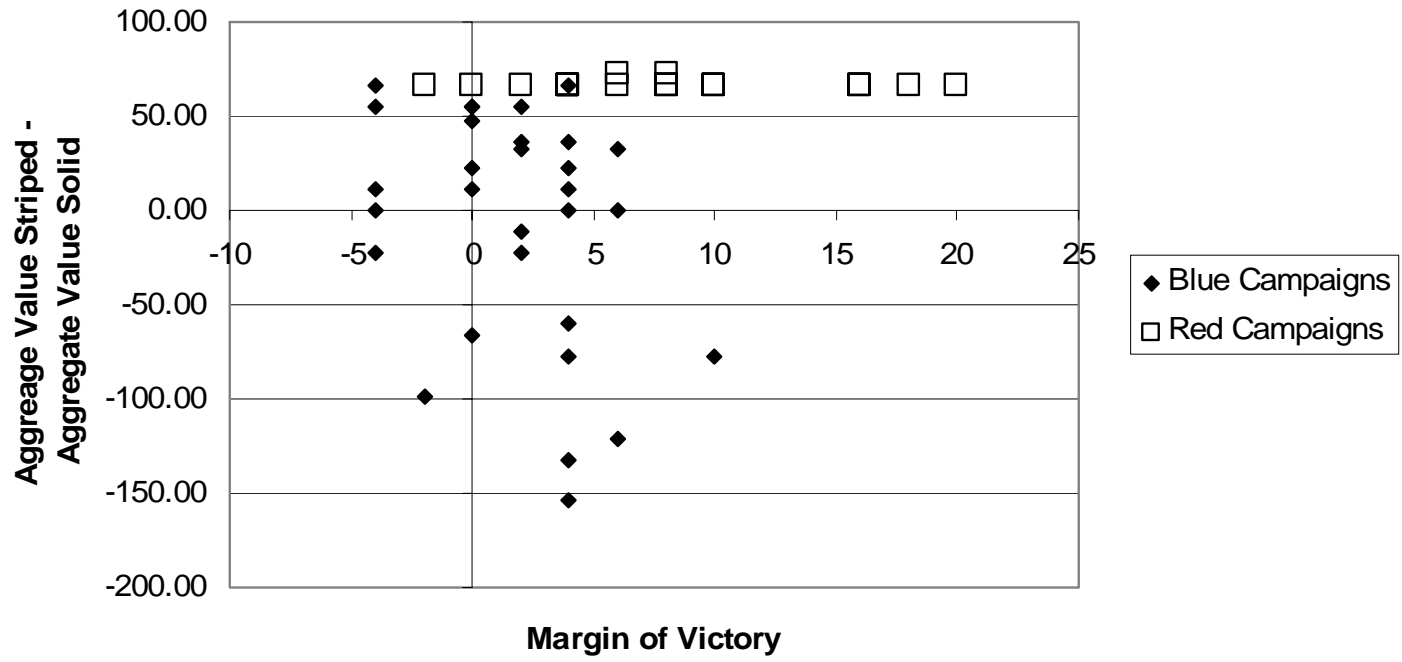




\section{IV.2. Policy Experiments}

While both experimental and theoretical evidence indicate that campaigns financed entirely by special interests are not appealing, neither is it necessarily practical to implement full public funding of campaigns. However, these baseline environments are on opposing ends of a wide spectrum of possible campaign finance strategies. In this section we report results from experiments designed to examine the welfare implications of two widely suggested campaign finance policies. In the first we impose spending caps on a fully special interest funded campaign. In the second we consider the case of public matching funds.

\section{IV.2.a. Spending Caps}

We implemented spending caps by restricting candidates in Blue campaigns to advertising at most five times. We chose five because that is the maximum number of ads that a high quality candidate in a Blue campaign can buy and still be the ex-post socially preferred choice. Both candidates and voters were aware when they were in this treatment.

Spending caps can be effective, in the sense that the right candidate is elected, if voters are sophisticated enough to recognize that they should definitely vote for a high quality candidate whose advertisement they receive. That is, one would like voters to respond to ads from high quality candidates in Cap treatments in the same way that they do in Red campaigns. We found, however, that voter behavior in Blue Cap campaigns was statistically identical to voter behavior in Blue campaigns. In particular, Figure 1 reveals that the estimated equation (1) for Cap campaigns is essentially identical to the analogous estimates for Blue campaigns. That is, voters who receive ads from the high quality candidate in the Cap campaigns are no more likely to vote for that candidate than they would be in the Blue campaigns. 
Overall then, the effects of spending caps are mixed. An advantage of caps is that, by construction, an elected high quality candidate will always provide positive social benefit. This is of course not the case in unrestricted special interest campaigns, where the elected candidate can provide negative social welfare. On the other hand, voters might not respond to advertising in Cap campaigns any differently than they do in regular special interest campaigns. In this event, the ex-post optimal, high quality candidate will be elected rather infrequently. In the case of our experiment, it was only about half of the time.

\section{IV.2.b. Matching Funds}

In this treatment we did not restrict the amount of candidate advertising. Instead, we provided candidates with one Red token for every Blue token that they used to buy an advertisement. That is, special interest funds were matched by public money one-to-one. Again, both voters and candidates were given full information about the nature of this treatment.

For matching funds to be effective it is necessary that candidates exercise some constraint in their spending, and also that voters are willing to treat matching campaigns more like Red campaigns than Blue campaigns. In fact, candidates did not always exercise restraint in their advertising, and subjects did not seem to change their decision behavior much from Blue campaigns (see Figure 1). As a result, out of 16 total campaigns, the ex-post optimal candidate was elected 11 times, but a socially less-preferred candidate was elected still twice.

The right candidate was elected more frequently in the matching treatment, but this treatment also includes the risk that the candidate will over-advertise and, if elected, provide a social cost. A matching treatment with caps (e.g., at most five blue tokens and five red tokens can be spent) would allow a high quality candidate to distribute information, and likely be 
elected, at a lower public cost than fully publicly funded campaigns.

\section{Conclusion}

Campaign finance is a leading topic in contemporary public policy debate. Theoretical work in this area has been vigorous and substantial progress has been made. In contrast, comparative empirical analyses of campaign finance policies, and especially their effects on welfare and electoral outcomes, have been slow to emerge due to lack of informative field data. This paper reported data from a laboratory investigation of campaign finance policy. Our experiment is disciplined by and complements formal theory on this topic.

One of our key results is that voters update their beliefs in a way that is consistent with theory. In particular, when campaigns are publicly financed, voters cast their ballot for the high quality candidate, regardless of the number of ads from that candidate that they have seen. This is not the case when campaigns are financed by quid-pro-quo special interest contributions. In these cases, voters of a high quality candidate's own party will often cast their ballot for an alternative, lower quality candidate when they have seen many of the high quality candidate's advertisements. In addition, voters from the opposition party will switch to the high quality candidate when they have seen that candidate's advertisement. These data indicate that voter belief revision is in the direction predicted by formal theory, and suggests that theory does not necessarily place unreasonable demands on behavior.

We pointed out that, in our environment, receiving two ads from the same candidate during a "quid-pro-quo" campaign is a strong signal that the candidate has over-advertised, leaving the other candidate as the earnings maximizing choice. However, while we noted that 
voters change decisions in this direction, we also showed that they do not do so in a strong enough way. Consequently, heavily advertising high quality candidates with significant specialinterest obligations are frequently elected. As a result, voter welfare in our environment would be higher if candidates faced spending caps. It is interesting to note that voters in a number of states, including Arizona, Nevada, California, Colorado, and Oregon, have voted on initiatives to limit campaign contributions. In the naturally occurring world, voters might recognize that they could benefit from caps.

Our laboratory campaigns included a relatively large number of subjects making decisions via sophisticated software that we developed specifically to study topics in political competition. ${ }^{8}$ Our software is flexible, and accommodates many potentially fruitful extensions of our design. One interesting possibility is to relax the restriction that only positive advertising is allowed, and to incorporate negative advertising. We are optimistic that such investigations could yield additional insights valuable for both theoretical and empirical research.

\footnotetext{
${ }^{8}$ Scholars interested in using this software for their own research are encouraged to contact the authors.
} 


\section{References}

Abrajano Marisa A. and Rebecca B. Morton, [2004] "All Style and No Substance? The Strategic Calculus of Campaign Advertising,” working paper, New York University.

Abramowitz, Alan. [1988]. "Explaining Senate Election Outcomes,” American Political Science Review, 82, pp.385-403.

Ashworth, Scott, [2003], “Campaign Finance and Voter Welfare with Entrenched Incumbents,” mimeo, Harvard University.

Austen-Smith, David, [1987], "Interest Groups, Campaign Contributions and Probabilistic Voting,” Public Choice, 54, 123-139.

Bailey, Michael, [2002], "Money and Representation: An Exploration in Multiple Dimensions with Informative Campaigns,” mimeo, Georgetown University.

Bailey, Michael, [2004], "The (Sometimes Surprising) Consequences of Societally Unrepresentative Contributors on Legislative Responsiveness.” Business and Politics, 6, 3 pp.134.

Baron, David, [1994], "Electoral Competition with Informed and Uninformed Voters,” American Political Science Review, 88, 33-47.

Coate, Stephen, [2004a], “Pareto Improving Campaign Finance Policy,” American Economic Review, 94,628-55.

Coate, Stephen, [2004b], "Political Competition with Campaign Contributions and Informative Advertising,” 2, 5 Journal of the European Economic Association, 2, 5, pp. 772 - 804

Freeman, John and Daniel Houser. [1998]. "A computable general equilibrium model for the study of the political economy.” American Journal of Political Science, 42:4, 1289-1320.

Gerber, Alan. [1998] "Estimating the Effect of Campaign Spending on Senate Election Outcomes Using Instrumental Variables", American Political Science Review,, 92, pp.401-11.

Green, Donald and Jonathan Krasno. [1988]. "Salvation for the Spendthrift Incumbent: Reestimating the Effects of Campaign Spending in House Elections,” American Journal of Political Science, 32, 884-907.

Groseclose, Timothy, [2001], “Character, Charisma, and Candidate Locations: A Model of Candidate Location when One Candidate Has a Valence Advantage,” American Journal of Political Science, 45, 862-886. 
Grossman, Gene and Elhanan Helpman, [1994], “Protection for Sale,” American Economic Review, 84, 833-850.

Grossman, Gene and Elhanan Helpman, [1996], "Electoral Competition and Special Interest Politics,” Review of Economic Studies, 63(2), pp.265-286.

Grossman, Gene and Elhanan Helpman, [2001], Special Interest Politics, Cambridge, MIT Press.

Hinich, Melvin J. and Michael Munger. [1989], "Political Investment, Voter Perceptions, and Candidate Strategy: An Equilibrium Spatial Analysis,” in Peter C. Ordeshook, ed, Models of Strategic Choice in Politics, Ann Arbor, MI: University of Michigan Press, pp. 49-68.

Houser, Daniel, Michael Keane and Kevin McCabe. [2004]. "Behavior in a dynamic decision problem: An analysis of experimental evidence using a Bayesian type classification algorithm," Econometrica, 72:3 (May), 781-822.

Houser, Daniel and Robert Kurzban. [2002]. "Revisiting kindness and confusion in public goods experiments.” American Economic Review, September, 92:4, 1062-1069.

Jacobson, Gary. [1980]. Money in Congressional Elections, New Haven: Yale University Press. Jacobson, Gary. [1985]. “Money and Votes Reconsidered: Congressional Elections 1972-1982,” Public Choice, 47, pp.7-62.

Jacobson, Gary. [1989]. "Strategic Politicians and the Dynamics of House Elections, 1946-86," American Political Science Review, 83, 773-793.

Jacobson, Gary. [1997]. The Politics of Congressional Elections, $4^{\text {th }}$ Edition, New York: Longman.

Jacobson, Gary, [1997], The Politics of Congressional Elections, 4th Edition, New York: Longman.

Kurzban, Robert and Daniel Houser. [2005]. "An experimental investigation of cooperative types in human groups: A complement to evolutionary theory and simulation," Proceedings of the National Academy of Sciences of the United States of America, 102(5), 1803-1807.

Levitt, Steven. [1994]. "Using Repeat Challengers to Estimate the Effects of Campaign Spending on Election Outcomes in the U.S. House,” Journal of Political Economy, 102, 777-798.

Morton, Rebecca B. and Charles Cameron, [1992], "Elections and the Theory of Campaign Contributions: A Survey and Critical Analysis,” Economics and Politics, 4, 79-108.

Morton, Rebecca B. and Roger B. Myerson. [2003], "Decisiveness of Campaign Contributions in Elections,” working paper, New York University. 
Potters, Jan, Randolph Sloof and Frans van Winden, [1997], “Campaign Expenditures, Contributions, and Direct Endorsements: The Strategic Use of Information and Money to Influence Voter Behavior,” European Journal of Political Economy, 13, 1-31.

Prat, Andrea, [2002a], “Campaign Advertising and Voter Welfare,” Review of Economic Studies, 69(4), 999-1018.

Prat, Andrea, [2002b], "Campaign Spending with Office-Seeking Politicians, Rational Voters, and Multiple Lobbies,” Journal of Economic Theory, 103(1), 162-189.

Simon, Adam. [2002], The Winning Messsage: Candidate Behavior, Campaign Discourse, and Democracy. Cambridge: Cambridge University Press.

Smith, Bradley A. [1995] "Campaign Finance Regulation: Faulty Assumptions and Undemocratic Consequences" Cato Policy Analysis, no. 238, September 13, 1995.

Stratmann, Thomas, [1998], "The Market for Congressional Votes: Is the Timing of Contributions Everything?" Journal of Law and Economics, 41, 85-114.

Stratmann, Thomas, [2002] "Can Special Interests Buy Congressional Votes? Evidence from Financial Services Legislation.” Journal of Law and Economics, Vol. XLV (2), pp. 345-74.

Stratmann, Thomas, [2004] "Contribution Limits and the Effectiveness of Campaign Spending.” Working Paper. George Mason University.

Schultz, Christian, [2003], “Strategic Campaigns and Redistributive Politics,” mimeo, University of Copenhagen.

Wittman, Donald, [2004a]. "Candidate Quality, Pressure Group Endorsements, and the Nature of Political Advertising,” working paper, Economics Department, University of California, Santa Cruz.

Wittman, Donald. [2004b]. "Pressure Groups and Political Advertising: How Uninformed Voters Can Use Strategic Rules of Thumb,” working paper, Economics Department, University of California. Santa Cruz. 


\section{Appendix: Subjects' Instructions}

\section{Insturctions for Experiment}

Welcome to today's experiment! You will be taking part in a decision making study. We are interested in your decisions that you make on your own. That means, now that the experiment has started, you may not talk to anyone except the experimenter. Please turn off all phones, beepers, and any other electronic devices. If you talk or otherwise communicate with another participant during the experiment, or if an electronic device of yours disturbs the experiment, you will be asked to leave and will collect only your show-up bonus. If you have any questions at any time during the experiment, please raise your hand, and we will come to you to answer your question.

VERY IMPORTANT: If you should experience any software problems at all (a program freeze, a system error message, etc.), do not touch the computer. Do not click to close any system error screens. Instead, please raise your hand, and we will assist you.

When you are finished reading a screen, click the Next button to continue.

For your participation, you will be paid a show-up bonus. You may earn more money during the course of the experiment, as explained in detail below. The experiment will take about two hours. Please remain quiet after the experiment has concluded. Each of you will be called to the experimenter, one-by-one, to be paid your earnings privately. After you have been paid you should exit the lab.

As you proceed through these instructions, there will be a quiz question at the bottom of each page. You must answer the question correctly before going to the next page. When you finish the instructions, you will play a simulated version of the experiment so that you can thoroughly familiarize yourself with the interface.

In this experiment you will be assigned randomly to the role of either candidate or voter. Two participants will be candidates, and the rest will be voters. Candidates campaign, and at the end of the campaign voters vote. There will be several campaigns during the experiment, so there is a chance that you will be both a candidate and a voter (there is also a chance that you will be only a voter). Therefore, during these instructions, you will familiarize yourself with both the candidate and the voter interfaces and rules.

Question: How many participants will be candidates during any given campaign?
A: 1
C: 3
B: 2
$\mathrm{D}$ : varies from campaign to campaign 
Whether you are a candidate or a voter, you will be randomly assigned to a political party. This experiment is a twoparty experiment. The two parties are the Circle Party and the Triangle Party. One candidate will be a Circle candidate, and the other candidate will be an Triangle candidate. There is an even number of voters, so in each campaign half the voters will be Circle party and half will be Triangle party.

You will be randomly reassigned to a party at the beginning of each of the campaigns. Party assignment will not affect your ability to earn payoffs during the experiment.

Question: If you are a Circle candidate in campaign 1, how many times is it possible for you to be assigned to the Circle party in subsequent campaigns?
A: None
C: 1
B: No limit
D: 2

A candidate always prefers to have a person from their party elected. For example, a Circle candidate will always prefer to elect a Circle candidate, and a Triangle candidate will always prefer to elect a Triangle candidate.

If you are a voter, there might be circumstances in which you could be better off if the candidate from the other party is elected. For example, if you are assigned to the role of a Triangle voter, then there may arise a situation where you would be better off if the Circle candidate won the election.

In addition to the candidates being assigned to a party, they will also be randomly assigned to either Solid or Striped.

The amount you earn in this experiment will depend partly on which candidate wins the election. Your earnings depend on whether the winning candidate belongs to your party, and whether they are a Solid or Striped candidate. You earnings also depend on the campaign decisions of the winning candidate, as described in detail below.

The campaign proceeds as follows. For 1 minute (marked by a countdown timer in the upper corner of your screen), candidates will campaign. After this, all campaigning will stop, and all participants will vote for their preferred candidate. The voting phase will last for 30 seconds. Both voters and candidates must vote.

During the campaign phase, voters observe candidates' activity on their computer screens. Candidates campaign by advertising. Each advertisement will reach exactly one voter. The voter who receives an advertisement is chosen randomly, with each voter equally likely to see any advertisement. As a candidate, you might have purchased eight advertisements, but this does not necessarily mean you have reached eight unique voters: the same voter can be reached multiple times while other voters are reached no times. You will not be told the party affiliation of the voters you reached.

Question: If you are a voter, what is the minimum number of advertisements you will see during the campaign?
A: 1
C: 0
B: 3
D: 2

A candidate can advertise only true information about his or her quality. For example, an advertisement from a Triangle-Striped candidate reads as follows:

"You have observed an advertisement from the Triangle candidate who is revealed to be Striped."

An advertisement from a Triangle-Solid candidate will read as follows:

"You have received an advertisement from the Triangle candidate who is revealed to be Solid."

Candidates pay for advertising with tokens. One token pays for one advertisement. There are four colors of tokens: 
Yellow, Blue, Red and Purple. Tokens are given to candidates at the beginning of the experiment, and candidates may purchase advertisements using any color of token available to them. Only the individual candidate knows how the advertising was purchased. For example, you are a Triangle candidate, and you purchase one advertisement using one Purple token. Your advertisement will reach one voter, but that voter will not be told that you made the purchase with a Purple token.

Question: You are a voter. In the current campaign, candidates are given Yellow and Blue tokens to use to buy advertisements. You receive an advertisement from a candidate. What color token was used to purchase the advertisement you saw?
A: Blue
C: Yellow
B: Red or Blue
D: Yellow Or Blue

Advertising is always costly to candidates. Each advertisement reduces a candidate's total experimental earnings by 10 cents.

Q: If you are a candidate, and during the campaign you have used 3 Red tokens and 4 Blue tokens, by how much will your earnings be reduced?
A: $\$ 0.70$
C: $\$ 2.70$
B: $\$ 2.00$
D: $\$ 2.30$

Advertisements are costly to voters only if a candidate uses Blue tokens to pay for advertising.

\section{If a candidate is elected, and that candidate has used Blue tokens to pay for advertising, then each voter's earnings are reduced by 50 cents for each Blue token that has been used by the elected candidate.}

You are a voter. If an elected candidate advertised 5 times, and three of those advertisements were purchased with Blue tokens, by what amount is each voter's payoff reduced?
A: $\$ 1.00$
C: $\$ 1.50$
B: $\$ 0.50$
D: $\$ 3.00$

A voter's screen will show the history of all advertisements that have been seen. You will have information only on messages you have received. You will not know how much either candidate has advertised or which other voters have seen advertisements.

At the end of the campaign phase, there will be a 30-second voting period. All participants must vote, as discussed previously. Whether you are a candidate or a voter, you will see a voting window which allows you to press a button corresponding to the candidate you wish to vote for. When you press the button, a message box will appear asking you to confirm your vote. You will not be able to change your vote once it has been confirmed, nor can you vote a second time. The election results will be shown to all participants. You will see the results along with your personal earnings for the campaign.

\section{Voter Earnings}

Voters' earnings are calculated in two steps.

The first step in calculating voters' earnings is as follows.

* The candidate in your party wins and that candidate is stripes: You earn \$7.50.

* The other party’s candidate wins and that candidate is stripes: You earn \$7.00.

* Your party’s candidate wins and that candidate is solids: You earn \$4.50.

* The other party’s candidate wins and that candidate is solids: You earn \$4.00. 
The second step in calculating voters' earnings is as follows.

If Blue tokens were used by the elected candidate, then each voter's earnings will be reduced by $\$ 0.50$ per Blue token used.

(You may need to use the $<$ Back $>$ button to view the previous screen in answering this question)

Q: You are a Circle voter. A stripes Triangle candidate wins the election, and used six Blue tokens during the campaign. What are your earnings?
A: $\$ 7.00$
C: $\$ 4.50$
B: $\$ 4.00$
D: $\$ 3.50$

\section{Candidate Earnings}

Candidates' earnings are calculated as follows. Because each candidate wants only their party to win, the first two steps are not used to calculate candidates' earnings.

The first step in calculating candidate's earnings is as follows.

First, a candidate will earn a bonus of $\$ 15$ if he/she is elected.

Also, a candidate’s earnings are reduced by $\$ 0.10$ for every advertisement that he/she has purchased.

Candidates do not earn any money from tokens that are not used.

Here is an example: You are a Circle-Striped candidate. You win the election in a Blue token campaign. During the campaign you use 11 Blue tokens to buy 11 advertisements. Your earnings are calculated by adding together the following: \$15 because you won the election, and $-\$ 1.10(\$ 0.10 * 11)$ due to the 11 advertisements. Your earnings for the campaign, therefore, are $\$ 15-\$ 1.10=\$ 13.90$.

Here is a second example: You are a Circle-Solid candidate. You lose the election in a Red token campaign. During the campaign you purchased 1 advertisement. Your earnings are as follows: \$0 because you did not win the election, and $-\$ 0.10$ due to the 1 advertisement. Your earnings for the campaign, therefore, are $\$ 0-\$ 0.10=\$-0.10$.

While it is possible for you as a candidate to lose money during an individual campaign, your earnings for the experiment will be positive.

You have now learned how the entire campaign process works for both voters and for candidates. There will be multiple campaigns in the experiment. Before each campaign begins, an information screen will be displayed for you. This screen will tell you what tokens are available for the upcoming campaign, whether you are a voter or a candidate, your party affiliation, and, if you are a candidate, whether you are stripes or solids. These characteristics will be randomly reassigned each campaign. At the conclusion of the final campaign, a summary screen will display your total earnings including your show-up fee.

Please sit quietly after the experiment has concluded and wait to be called to receive your earnings.

You will now go through three practice screens: first the Candidate screen, second the Voter screen, and third the Voting screen. Screens will display for 1 minute each. Practice clicking the different buttons in the window to see how the interface works.

Click the $<$ Finished $>$ button to begin the practice screens. 


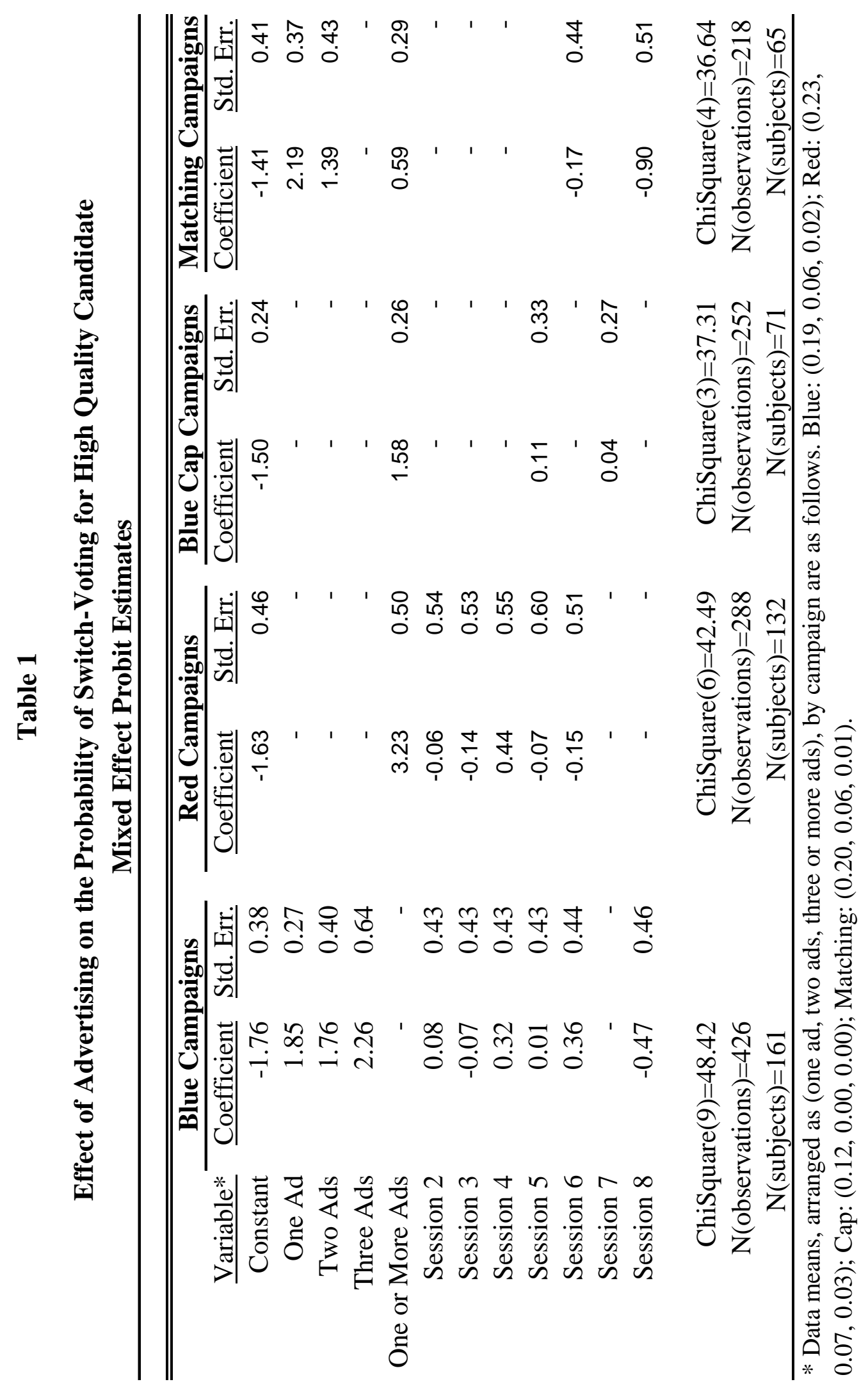




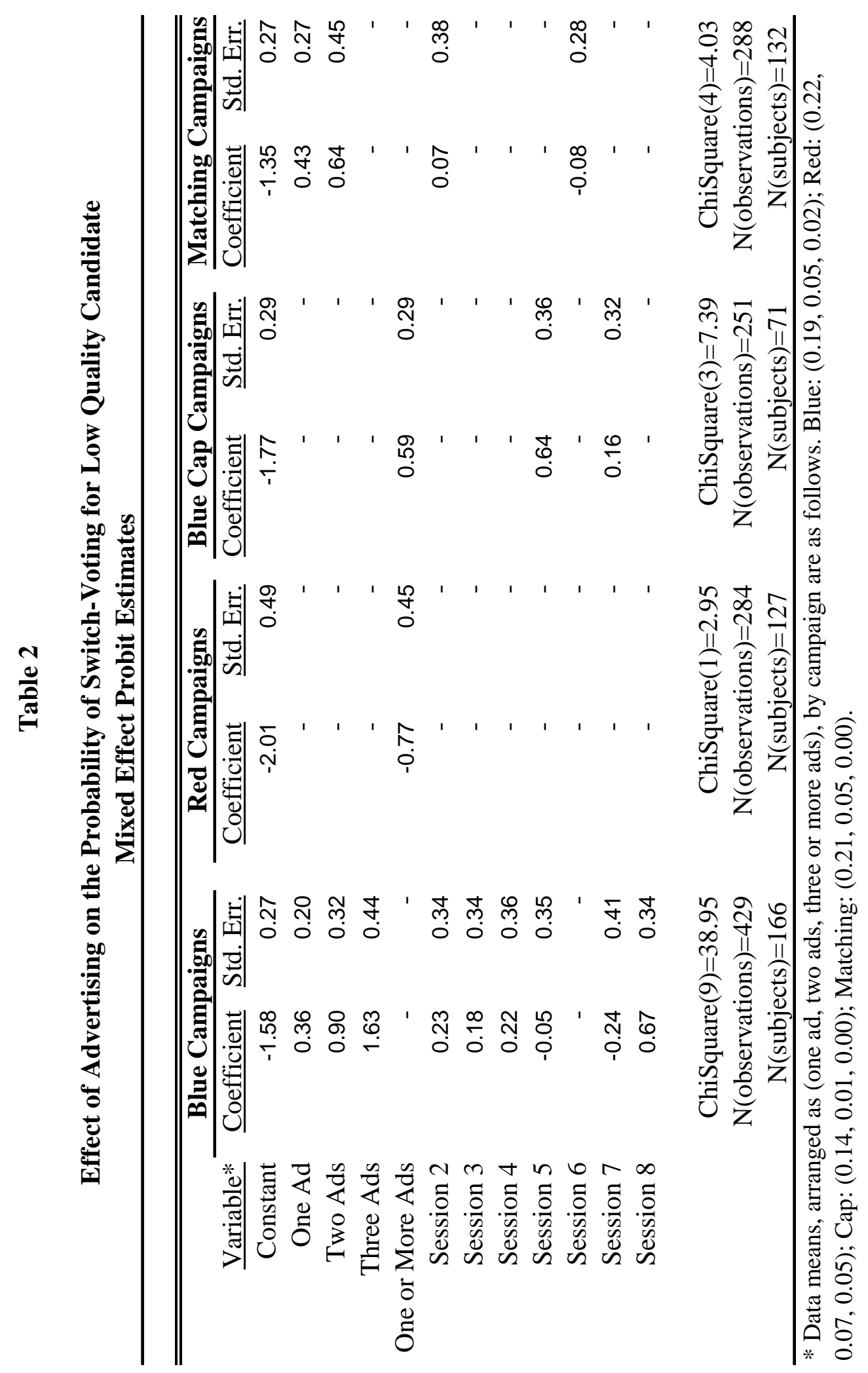


Table A1

Expected Number of Ads Received by Number of Ads Sent*

\begin{tabular}{rccccc}
\hline \hline & \multicolumn{5}{c}{ Number of Ads Received } \\
\cline { 2 - 6 } Number of Ads Sent & $\underline{0}$ & $\underline{1}$ & $\underline{3}$ & $\underline{3}$ & $\underline{4}$ \\
0 & 1.00 & 0.00 & 0.00 & 0.00 & 0.00 \\
1 & 0.96 & 0.04 & 0.00 & 0.00 & 0.00 \\
2 & 0.92 & 0.07 & 0.00 & 0.00 & 0.00 \\
3 & 0.89 & 0.11 & 0.00 & 0.00 & 0.00 \\
4 & 0.86 & 0.14 & 0.01 & 0.00 & 0.00 \\
5 & 0.82 & 0.16 & 0.01 & 0.00 & 0.00 \\
6 & 0.79 & 0.19 & 0.02 & 0.00 & 0.00 \\
7 & 0.76 & 0.21 & 0.03 & 0.00 & 0.00 \\
8 & 0.73 & 0.23 & 0.03 & 0.00 & 0.00 \\
9 & 0.70 & 0.25 & 0.04 & 0.00 & 0.00 \\
10 & 0.68 & 0.27 & 0.05 & 0.01 & 0.00 \\
11 & 0.65 & 0.29 & 0.06 & 0.01 & 0.00 \\
12 & 0.62 & 0.30 & 0.07 & 0.01 & 0.00 \\
13 & 0.60 & 0.31 & 0.08 & 0.01 & 0.00 \\
14 & 0.58 & 0.32 & 0.08 & 0.01 & 0.00 \\
15 & 0.55 & 0.34 & 0.09 & 0.02 & 0.00 \\
16 & 0.53 & 0.34 & 0.10 & 0.02 & 0.00 \\
17 & 0.51 & 0.35 & 0.11 & 0.02 & 0.00 \\
18 & 0.49 & 0.36 & 0.12 & 0.03 & 0.00 \\
19 & 0.47 & 0.36 & 0.13 & 0.03 & 0.00 \\
20 & 0.46 & 0.37 & 0.14 & 0.03 & 0.01 \\
25 & 0.38 & 0.37 & 0.18 & 0.06 & 0.01 \\
30 & 0.31 & 0.37 & 0.21 & 0.08 & 0.02 \\
40 & 0.21 & 0.33 & 0.26 & 0.13 & 0.05 \\
50 & 0.14 & 0.28 & 0.28 & 0.18 & 0.08 \\
\hline
\end{tabular}

* This table shows the expected fraction of voters who will see $\mathrm{N}$ ads conditional on $\mathrm{M}$ ads being sent. For example, when zero ads are sent, then $100 \%$ of voters are expected to see zero ads. When 10 ads are sent, $68 \%$ of voters are expected to see exactly zero ads, and $5 \%$ are expected to see exactly two ads. This table was calculated by simulating the advertising process according to the specifications described in the body of the text, under the assumption that there are 24 voters and two candidates. 


\section{CESifo Working Paper Series}

(for full list see www.cesifo-group.de)

1665 Samuel Muehlemann and Stefan C. Wolter, Regional Effects on Employer Provided Training: Evidence from Apprenticeship Training in Switzerland, February 2006

1666 Laszlo Goerke, Bureaucratic Corruption and Profit Tax Evasion, February 2006

1667 Ivo J. M. Arnold and Jan J. G. Lemmen, Inflation Expectations and Inflation Uncertainty in the Eurozone: Evidence from Survey Data, February 2006

1668 Hans Gersbach and Hans Haller, Voice and Bargaining Power, February 2006

1669 Françoise Forges and Frédéric Koessler, Long Persuasion Games, February 2006

1670 Florian Englmaier and Markus Reisinger, Information, Coordination, and the Industrialization of Countries, February 2006

1671 Hendrik Hakenes and Andreas Irmen, Something out of Nothing? Neoclassical Growth and the 'Trivial' Steady State, February 2006

1672 Torsten Persson and Guido Tabellini, Democracy and Development: The Devil in the Details, February 2006

1673 Michael Rauber and Heinrich W. Ursprung, Evaluation of Researchers: A Life Cycle Analysis of German Academic Economists, February 2006

1674 Ernesto Reuben and Frans van Winden, Reciprocity and Emotions when Reciprocators Know each other, February 2006

1675 Assar Lindbeck and Mats Persson, A Model of Income Insurance and Social Norms, February 2006

1676 Horst Raff, Michael Ryan and Frank Staehler, Asset Ownership and Foreign-Market Entry, February 2006

1677 Miguel Portela, Rob Alessie and Coen Teulings, Measurement Error in Education and Growth Regressions, February 2006

1678 Andreas Haufler, Alexander Klemm and Guttorm Schjelderup, Globalisation and the Mix of Wage and Profit Taxes, February 2006

1679 Kurt R. Brekke and Lars Sørgard, Public versus Private Health Care in a National Health Service, March 2006

1680 Dominik Grafenhofer, Christian Jaag, Christian Keuschnigg and Mirela Keuschnigg, Probabilistic Aging, March 2006 
1681 Wladimir Raymond, Pierre Mohnen, Franz Palm and Sybrand Schim van der Loeff, Persistence of Innovation in Dutch Manufacturing: Is it Spurious?, March 2006

1682 Andrea Colciago, V. Anton Muscatelli, Tiziano Ropele and Patrizio Tirelli, The Role of Fiscal Policy in a Monetary Union: Are National Automatic Stabilizers Effective?, March 2006

1683 Mario Jametti and Thomas von Ungern-Sternberg, Risk Selection in Natural Disaster Insurance - the Case of France, March 2006

1684 Ken Sennewald and Klaus Waelde, "Itô's Lemma“ and the Bellman Equation for Poisson Processes: An Applied View, March 2006

1685 Ernesto Reuben and Frans van Winden, Negative Reciprocity and the Interaction of Emotions and Fairness Norms, March 2006

1686 Françoise Forges, The Ex Ante Incentive Compatible Core in Exchange Economies with and without Indivisibilities, March 2006

1687 Assar Lindbeck, Mårten Palme and Mats Persson, Job Security and Work Absence: Evidence from a Natural Experiment, March 2006

1688 Sebastian Buhai and Coen Teulings, Tenure Profiles and Efficient Separation in a Stochastic Productivity Model, March 2006

1689 Gebhard Kirchgaessner and Silika Prohl, Sustainability of Swiss Fiscal Policy, March 2006

1690 A. Lans Bovenberg and Peter Birch Sørensen, Optimal Taxation and Social Insurance in a Lifetime Perspective, March 2006

1691 Moritz Schularick and Thomas M. Steger, Does Financial Integration Spur Economic Growth? New Evidence from the First Era of Financial Globalization, March 2006

1692 Burkhard Heer and Alfred Maussner, Business Cycle Dynamics of a New Keynesian Overlapping Generations Model with Progressive Income Taxation, March 2006

1693 Jarko Fidrmuc and Iikka Korhonen, Meta-Analysis of the Business Cycle Correlation between the Euro Area and the CEECs, March 2006

1694 Steffen Henzel and Timo Wollmershaeuser, The New Keynesian Phillips Curve and the Role of Expectations: Evidence from the Ifo World Economic Survey, March 2006

1695 Yin-Wong Cheung, An Empirical Model of Daily Highs and Lows, March 2006

1696 Scott Alan Carson, African-American and White Living Standards in the $19^{\text {th }}$ Century American South: A Biological Comparison, March 2006

1697 Helge Berger, Optimal Central Bank Design: Benchmarks for the ECB, March 2006 
1698 Vjollca Sadiraj, Jan Tuinstra and Frans van Winden, On the Size of the Winning Set in the Presence of Interest Groups, April 2006

1699 Martin Gassebner, Michael Lamla and Jan-Egbert Sturm, Economic, Demographic and Political Determinants of Pollution Reassessed: A Sensitivity Analysis, April 2006

1700 Louis N. Christofides and Amy Chen Peng, Major Provisions of Labour Contracts and their Theoretical Coherence, April 2006

1701 Christian Groth, Karl-Josef Koch and Thomas M. Steger, Rethinking the Concept of Long-Run Economic Growth, April 2006

1702 Dirk Schindler and Guttorm Schjelderup, Company Tax Reform in Europe and its Effect on Collusive Behavior, April 2006

1703 Françoise Forges and Enrico Minelli, Afriat’s Theorem for General Budget Sets, April 2006

1704 M. Hashem Pesaran, Ron P. Smith, Takashi Yamagata and Liudmyla Hvozdyk, Pairwise Tests of Purchasing Power Parity Using Aggregate and Disaggregate Price Measures, April 2006

1705 Piero Gottardi and Felix Kubler, Social Security and Risk Sharing, April 2006

1706 Giacomo Corneo and Christina M. Fong, What's the Monetary Value of Distributive Justice?, April 2006

1707 Andreas Knabe, Ronnie Schoeb and Joachim Weimann, Marginal Employment Subsidization: A New Concept and a Reappraisal, April 2006

1708 Hans-Werner Sinn, The Pathological Export Boom and the Bazaar Effect - How to Solve the German Puzzle, April 2006

1709 Helge Berger and Stephan Danninger, The Employment Effects of Labor and Product Markets Deregulation and their Implications for Structural Reform, May 2006

1710 Michael Ehrmann and Marcel Fratzscher, Global Financial Transmission of Monetary Policy Shocks, May 2006

1711 Carsten Eckel and Hartmut Egger, Wage Bargaining and Multinational Firms in General Equilibrium, May 2006

1712 Mathias Hoffmann, Proprietary Income, Entrepreneurial Risk, and the Predictability of U.S. Stock Returns, May 2006

1713 Marc-Andreas Muendler and Sascha O. Becker, Margins of Multinational Labor Substitution, May 2006

1714 Surajeet Chakravarty and W. Bentley MacLeod, Construction Contracts (or "How to Get the Right Building at the Right Price?’), May 2006 
1715 David Encaoua and Yassine Lefouili, Choosing Intellectual Protection: Imitation, Patent Strength and Licensing, May 2006

1716 Chris van Klaveren, Bernard van Praag and Henriette Maassen van den Brink, Empirical Estimation Results of a Collective Household Time Allocation Model, May 2006

1717 Paul De Grauwe and Agnieszka Markiewicz, Learning to Forecast the Exchange Rate: Two Competing Approaches, May 2006

1718 Sijbren Cnossen, Tobacco Taxation in the European Union, May 2006

1719 Marcel Gérard and Fernando Ruiz, Interjurisdictional Competition for Higher Education and Firms, May 2006

1720 Ronald McKinnon and Gunther Schnabl, China's Exchange Rate and International Adjustment in Wages, Prices, and Interest Rates: Japan Déjà Vu?, May 2006

1721 Paolo M. Panteghini, The Capital Structure of Multinational Companies under Tax Competition, May 2006

1722 Johannes Becker, Clemens Fuest and Thomas Hemmelgarn, Corporate Tax Reform and Foreign Direct Investment in Germany - Evidence from Firm-Level Data, May 2006

1723 Christian Kleiber, Martin Sexauer and Klaus Waelde, Bequests, Taxation and the Distribution of Wealth in a General Equilibrium Model, May 2006

1724 Axel Dreher and Jan-Egbert Sturm, Do IMF and World Bank Influence Voting in the UN General Assembly?, May 2006

1725 Swapan K. Bhattacharya and Biswa N. Bhattacharyay, Prospects of Regional Cooperation in Trade, Investment and Finance in Asia: An Empirical Analysis on BIMSTEC Countries and Japan, May 2006

1726 Philippe Choné and Laurent Linnemer, Assessing Horizontal Mergers under Uncertain Efficiency Gains, May 2006

1727 Daniel Houser and Thomas Stratmann, Selling Favors in the Lab: Experiments on Campaign Finance Reform, May 2006 